\title{
Implementation of Interculturality in Early Education
}

\author{
Luka Pongračić ${ }^{1, *}$, Ana Maria Marinac ${ }^{2}$ \\ ${ }^{1}$ Faculty of Educational Sciences, Juraj Dobrila University of Pula, Croatia \\ ${ }^{2}$ Faculty of Education, University of J. J. Strossmayer in Osijek, Croatia
}

\begin{abstract}
.
The upbringing aspect of education is often neglected for various reasons and influences. Overloaded with the amount and rate of mastering the content often throws upbringing into the background. The methodology of this paper consists of a qualitative review and analysis of domestic and foreign literature and researches with the aim of emphasizing the importance, but also ways to increase the levels of upbringing in the classroom. By analyzing different aspects of the teaching process, such as pluralism, the role of the family and different motivational contexts, there are opportunities to increase the level of upbringing. It is important in modern teaching to connect education with interculturalism, which is ubiquitous in the intercultural environment in which students attend classes, surrounded by members of different cultures and nationalities. The main goal of this paper is to point out the possibility of increasing the level of intercultural education during regular classes and to present and analyze the possibilities of implementing the intercultural nature of the educational and upbringing aspect in early education. In this way, the students we educate will be ready for the future intercultural challenges they will face on a daily basis.
\end{abstract}

Keywords: modern teaching; motivation; pluralism; readiness for the future; upbringing

\section{Introduction}

The teaching process has an educational and an upbringing aspect. What most people often observe (and evaluate) is just the educational aspect; how many different facts we have taught the children, what they know how to retell and dictate. It is often this upbringing part that is neglected, which is rarely questioned, perhaps only when students do not greet the elder in the school hallway or on the street. Somehow, this upbringing paradigm is always the one that is less addressed, especially in the upper grades. The school is more focused on the educational than on the upbringing side of the process (Kolak, 2015).

The aim of this paper is to emphasize the special importance of upbringing items of the teaching process in order to amplify their usage, but also to ameliorate the critical aspect with which they are observed in pursuance of their development. The development of the educational process in the pluralistic paradigm is an indispensable part of our future and without such an approach schools will not develop in accordance with the students' requirements, as well as the opportunities provided by social and technological progress. The 
school must not be omitted in the development towards the future, so it is necessary to timely work on the development of an item that is already quite neglected, and that is upbringing. The environment in which we live is inevitably and indisputably multicultural, and without the development of interculturality in students it will not be an agreeable place to live in the future. Space for the development of intercultural competence is being opened in upbringing subjects, and classroom teaching is the core capital along the way.

\section{Methodology}

The methodology of this paper is a qualitative review and analysis of domestic and foreign literature and researches with the aim of emphasizing the importance and various ways to increase the levels of upbringing in the classroom. There has been done analysis of different aspects of the teaching process with special context of pluralism in education, the role of the family and different motivational contexts.

\subsection{The importance and pluralism of upbringing}

It may be trivial to write about the importance of upbringing, but this topic is a fundamental starting point for all further considerations of the success of achieving a comprehensive and purposeful teaching process. The educator ${ }^{1}$ (Parsons, 2007) is often placed at its centre, as the person around whom everything revolves and who plays the most important role in that individual process. He should have competencies, skills and abilities based on knowledge and demonstrate them in solving certain situations and problems (Weinert 1999, 2001) and in performing specific roles (Day, 1999). It is important that the educator knows that teaching is not methods, but the way in which they are used, i.e. what is done with them (Squires, 2004). While it is hard to ignore the paradigm that teaching to some people comes more intuitively than to others, there is no specific team of teacher personalities that is more effective than others. It is only important that students recognize that the teacher is for them, that is, on their side (Hayes, 2009). Pluralism is one of the most important efforts of upbringing:

To want upbringing for pluralism and pluralism in upbringing is the same as to want upbringing, and not manipulation, because the cultivation of man deprived of essence of upbringing - which means: it is precisely pluralism without which there is no and cannot be the development of personality - can never be upbringing nor the cultivation that follows and supports the internal biological developmental givenness of a being, but only the uniform external programming of human 'hardening' (hardware) to perform given functions (Polić, 2006, 32).

Seifert and Sutton (2009) cite two fundamental pathways of developmental trends in children. The first is general and is based on the assumption that development in all children occurs at relatively predictable periods of life - for example, each infant adopts spoken (mother) language; each adolescent adopts a sense of personal identity (ibid 41; Blos 1966; Lebedina-Manzoni \& Lothar, 2011). The second theory is that developmental changes are limited, occurring only in some and under certain circumstances - for example, the development of the female gender role takes place only in the female part of the population;

\footnotetext{
${ }^{1}$ The notion of educator is viewed here in the context of schoool teachers
} 
and the details depend on the family, community, and social environment in which the child develops (Seifert \& Sutton, 2009, B). Rogić (2003) distinguishes the interactionist hypothesis of identity development through communication and action; and a structural hypothesis that considers identity to be the imprint of social structure.

We must be aware of other aspects of upbringing, such as functional upbringing, which consists of everything that affects human knowledge, attitudes and skills, and is not the result of anyone's direct influence, but everyday (social) environment (Mužić, 1999; Vukasović, 2001; Jagić, 2006; Vujčić, 2013). ).

\subsection{Interculturality}

At the beginning of the debate on interculturality, it is necessary to determine where the demand for it stems from. Haviland (2004) cites the meaning of the term ethnocentrism which he defines as the belief of some group (culture) that exists well as if they are the best. In order to avoid ethnocentrism, it is necessary to strive for cultural relativism. It is a paradigm that instructs us that other cultures should be viewed within their customs and at the same time viewed objectively, that is, without condemnation and prejudice. Dervin (2014) explains what the prefix inter- means in the term interculturality. This is what takes place among (different) people during their shared activities, relationships and exchange of identities. Lafraya (2011; Vrcelj, 2005) cites the difference between multiculturalism and interculturality. Multiculturalism is a state where several different cultures are located in one place or area; while interculturality is a relationship, an interactive connection between different cultures.

The most important and dignified challenge that today's society must support is the interaction of diverse cultural, ethnic and religious groups as well as different social minorities and movements that form a versatile mosaic of the global society of the new Europe. Every human community should strive for pluralism and tolerance in order to prevent conflicts that arise due to the indifference to the needs of others to express their own identity (Ninčević, 2009, 60).

Interculturalism involves overcoming the challenges of (communicative) interactions in which participants have different cultures and speak different languages. Intercultural values are found in successfully establishing communication, working in a team, and overcoming differences together (Jackson, 2014).

Teachers are the drivers of the value of interculturalism (Mlinarević \& Brust-Nemet 2012) with their teaching on tolerance and equality. The school should raise students in modern, democratic values and develop interpersonal and interethnic relations, as well as respect for diversity (Gajić, 2011). It is necessary to start from a good knowledge of one's own culture and identity in order to develop respect for diversity through an open access to other cultures (Račić, 2013); but it is important (also) for teachers to build their multicultural attitudes so that they can teach and encourage their students to think critically about them (Hal \& Lofstrom, 2016).

\subsection{The role of the family in cooperation with the school}

Parents are an important part of every young life, this is also evident when it comes to upbringing and education. The role of parents in upbringing is unquestionably important, and in order to achieve the best for the student, the education of parents and the cooperation of the 
school with the family is highly desirable. The importance of parent-school collaboration should not be questioned much. From the history of upbringing and education it can be seen that school and family were two separate parties, and their tasks were by no means the same. However, when education became compulsory, the importance of parents' cooperation with the school at a higher level began to be questioned. Parents should be school collaborators, the most important collaborators. When this is made possible, awareness is raised of how much the parent is co-responsible for the child's development. Working with parents brings a number of new challenges for every teacher or pedagogue, whether it is an individual or group work, but with good preparation and education, cooperation can be easily achieved and bring many positive effects (Lukaš \& Gazibara, 2010). It is often talked about how much the child-parent relationship affects students'school success. Sometimes parents are the biggest support, but they (un)consciously leave deep traces on their children, expecting from them what is generally expected of the best students, and thus put a lot of burden on the backs of their children.

When considering student workload, there are direct and indirect factors of student workload. Direct factors are teachers, timetables, textbooks and parents' expectations, while the indirect conditions are, for instance, school conditions, family conditions, extracurricular activities ... Parents often set unrealistic expectations, those that are not in line with the student's potential, and the child's school success is most often measured by a grade and therefore the child is expected to have high grades. Often only fives (or A's) mean good school success (Juričić, 2006). Parents' educational expectations and parental behaviour towards children often leave deep traces in them for almost a lifetime. Parents often unknowingly develop a negative aspect of perfectionism in their expectations of their children, which leaves certain consequences in the long run (Grbavac \& Slišković, 2015). The basic characteristics of perfectionism are: excessively high personal standards, excessive concern about performance errors, doubts about the quality of one's own performance, excessive emphasis on precision, work, organization, and the role of expectations and judgment by parents (Frost et al., 1990).

\subsection{Evaluation of Music, Art culture and Physical and health culture}

The question arises as to how and what to evaluate in subjects such as music and art culture or physical and health culture. I will first take music culture as an example. The aim of this subject in primary school is 'introducing students to music culture, learning the basic elements of musical language, developing musical creativity, establishing and adopting criteria for (critical and aesthetic) judgment of music'. In lower grades music culture includes activities such as singing listening, playing ... (Curriculum, 2006, 66). Teachers are quite free to teach music culture, which means that it is up to them how they will teach and what they will evaluate. Unfortunately, the lessons are often reduced to just listening to a certain song from the textbook and repeating it several times. Teachers are not interested enough in playing, but singing is (still) graded regularly in schools. Such assessments are not realistic and should not exist. A subject such as music culture can be a subject for students to rest and enjoy or a subject attended 'with a cramp' (depending on the teacher) because the student knows his classmates will ridicule him again because he 'can't sing.' Music culture should be much more than repetition of verses. As the name suggests, this subject is a musical culture, and therefore an upbringing subject. In this subject, students should learn to express themselves musically, adopt predicted terms, create critical thinking and learn to express it (I 
like the song because ...), but in addition to the educational part there is an important upbringing part, such as learning to listen, search, research, communicate, listen to others, learn that not everyone is the same, learn that everyone has different interests, opportunities, accept the advice of teachers, not to compare oneself with others, monitor and notice one's own progress, accept oneself... A teacher in music culture class must provide stimulating environments for students, design workshops and activities, engage in research of educational-upbringing problems encountered in practice. It is desirable that the primary school teacher participates with music pedagogues in the school, who could direct him towards what he wants to achieve (Gortan Carlin \& Močinić, 2017). As for the musical skills themselves, the teacher here has the opportunity to develop in some students a sense of rhythm, melody, improve hearing, etc. and therefore monitor the progress of each student. However, this should not be forced even in situations where the teacher deems them unsuitable for such activities. Teacher competencies are also important. Teachers did not come with the same opportunities either, however, as with students, teachers also have an ability to progress. Teachers at the teacher training course listen to various courses in the field of music art, but it is interesting that even during college a large number of students face great challenges in mastering the art of playing or singing that requires continuous work during all years of study and (as in teaching) combining formal, non-formal and informal ways of teaching and learning music content (Dobrota, 2016). Therefore, it is important that every teacher continues their education after graduating.

Art culture is one of the most specific subjects, it is mostly determined by its dynamism and less structure in respect of other subjects, and what makes it so are the numerous didacticmethodological, personal, social, material and other conditions (Tomljenović, 2016). The selection criteria are focused on the student, i.e. on the student opportunities and conditions in which teaching is conducted (Tacol, 2011). The teacher here too, much like in music culture, has a great responsibility and his prior knowledge and readiness are very important. The quality of teaching is reflected in the learning process of students. He also has a great responsibility in choosing the strategies he uses (Tomljenović, 2016, B). In art culture, the best works are often chosen and later hung on the board. However, every work is equally valuable, regardless of the final outcome, and this should not only be said but also shown, therefore every work should find its place on the board. Students should be taught here that effort yields good results and be evaluated according to the effort. This is a subject where the teacher can reach each student and go a little deeper into his thoughts according to his work. As students in art culture mainly deal with their work, the teacher has enough space to work on student self-confidence, has the opportunity to see what the situation is among students, how they relate to each other (usually students are divided into groups) ... Involving students in artistic processes develops a sense of creativity and initiative, emotional intelligence, a sense of independence and freedom of thought and action (Brajčić, 2015).

\subsection{Motivation and demotivation}

Motivation is an extremely important factor in successful work, not only in school, but in every job. One of the most important goals for a teacher is certainly to successfully motivate his students to work. Deci and Rayan (1995; 2000; Wigfield and Eccles 2002; Wigfield et al. 2008) cite the theory of cognitive evaluation according to which intrinsic motivators must prevail in order for an individual to be and remain motivated. Intrinsic needs can also be successful motivators, such as challenge, interest, belonging, accomplishment; and the person 
engages in activities for their own pleasure (Buble, 2011). Gutić and Rudelj (2012) distinguish motivation from motives. According to them, motivation is an experience and behaviour, and motives are what motivates them. It is important for the teacher to determine the right motives in order to achieve the highest possible motivation (or any kind of motivation to begin with). We should not forget the use value of extrinsic motivation, which is stimulated by external influences such as rewards and bonuses (Horga, 1993) and interaction among students (Sage \& Kindermann, 1999).

Motivation can also be seen as the first stage of a lesson (process), and is also called preparation, introduction or creation of mood (Jogan Linić, 2003), and its purpose is to prepare students so that they can communicate as fully and personally as possible. Motivation can be regulated by directed action to encourage and maintain the intention to work on a task, complete a particular activity, or achieve a goal (Wolters, 2011). One of the stimulating methods of teaching is project teaching. It meets the high demands of integrative teaching, develops perseverance, motivation, curiosity, self-confidence and greatly develops existing and new competencies. It is important for projects to set clear criteria and present them to students at the beginning. This type of work teaches students to separate the important from the irrelevant, develops collaborative work and is interdisciplinary, and prepares students for real life (Čudina-Obradović \& Brajković, 2009).

It is important to mention some characteristics of demotivation in order to know what to avoid. Dornyei and Ushikoda (2011) describe demotivation as specific external influences that reduce or eliminate motivation, and are based on behaviour or certain activities. The authors list three groups of situations that negatively affect student motivation, i.e. they are demotivating. The first are related to learning, and they are environmental pressure, overload and poor test results. The second group is related to the social environment - peer pressure, personality, attitudes of peers and teachers. The third group is related to the social context outside the classroom, and refers to the attitudes and factors of the environment, i.e. the community (ibid 138).

Kolak $(2015,155-156, \mathrm{~B})$ explores the issue of the crisis of the upbringing in the modern school. There are three different approaches to this problem cited by the author; the first is the optimistic approach according to which the crisis of upbringing is not a modern phenomenon, but because of the importance and significance of the process of upbringing was present all the time, varying in intensity. The second approach is pessimistic, which analyses only modern schools from the point of view that their upbringing activities are neglected and are not at the centre of more serious social focuses. The third approach is realistic, recognizing the continuity of the crisis and highlighting several major elements throughout history (and in the present): the school is more subject education oriented by definition, and the value system is vaguely and insufficiently precisely formulated.

\section{Conclusion}

References On the first day of compulsory education, most parents bring their first-graders to school. On that day, it would be good to acquaint parents with school, with their tasks, with the importance they have in the lives of their children, but also to open a place where they will always be able to turn when they encounter any possible difficulties. It should be emphasized at the outset that school and family work together, not against each other, and that the well- 
being and development of the child comes first. The first day will be taken as an example. Such a workshop should certainly be announced in advance, in order to prepare all the participants. Parents would enter the classroom with their children, which would give them extra security, and the separation of students from parents would probably be facilitated in this way. Furthermore, parents would be introduced to the work of the school and the cooperation of the school with the family. In order for the parents to feel important, it is also possible to ask them what they expect from the school and the teachers, anonymously or publicly. After receiving the answers, it is possible to open a discussion in order to further clarify each proposed item. Parents should also be introduced to textbooks, workbooks and other materials that students will use. It is possible to offer parents to try to process certain material individually with their child in one hour, together with the teacher, in this way the teacher could give specific instructions for improving the work of parents with the student etc.

Physical and health culture is also one of the subjects that students go to with joy or 'cramping', depending mostly on the teacher. In physical education and health, students also adopt certain concepts, encounter a new way of teaching (in the hall), perform different exercises, learn about different games ... A teacher of physical education and health should be primarily a support and example to students, and emphasis should be put on the path to the goal, not the goal. For example, if a student has adopted all the concepts, methodical procedure, if he is aware of his mistakes, but still cannot perform a particular exercise, the teacher should encourage him, motivate him, put emphasis on what he has achieved so far, progress and effort, and not on the fact that the student has not yet reached the desired goal proper performance of the exercise. Students in such situations should not be punished in any way. According to Rogulj, Ujević and Rogulj (2011) assessment from physical education and health is formed through several components. The most important component is the one that represents the motor knowledge and the quality of the implementation of techniques from certain sports. The second component represents motor achievements, which are a combination of the first component and anthropological characteristics of students. Then, functional abilities are evaluated, i.e. anthropological features that consist of morphological characteristics and motor and functional abilities. Only the last component presents grades from upbringing effects, such as regular attendance and participation in classes, activities and commitment of students, etc. In the class of physical education and health students should be informed that everyone is different and that they should support each other and this atmosphere should stem from the teacher himself.

\section{References}

[1] Blos, Peter. 1966. On Adolescence: A Psychoanalytic Interpreation. New York: The Free Press.

[2] Buble, Marin. 2011. Poslovno vođenje. Zagreb: M.E.P.

[3] Brajčić, Marija. 2015. Umjetnost i obrazovanje. Zbornik radova Filozofskoga fakulteta u Splitu, 2016. Retrived from: https://hrcak.srce.hr/index.php?show= clanak\&id_clanak_jezik=227810 (16. 5. 2020.)

[4] Čudina-Obradović, Mira i Brajković, Sanja. 2009. Integrirano poučavanje. Zagreb POU: Korak po korak. 
[5] Day, Cristopher. 1999. Developig Teachers, The Challenges of Lifelong Learning. London: Falmer Press.

[6] Deci, Edward i Ryan, Richard. 1995. Self-Determination Theory and the Facilitation of Intrinsic Motivation, Social Development and Well-Being. American Psychologist, 55 (1). 68-78. DOI: 10.1037/0003-066X.55.1.68

[7] Deci, Edward i Ryan, Richard. 2000. Intrinsic and extrinsic motivations: Classic definitions and new directions. Contemporary Educational Psychology, 25. 54-67.

[8] Dobrota, Snježana. 2016. Nastava glazbe u kontekstu formalnog i informalnog učenja. Zbornik znanstvenih radova s Međunarodne znanstvene konferencije Globalne i lokalne perspektive pedagogije. Ur. Jukić, Renata i sur. Osijek: Filozofski fakultet u Osijeku.

[9] Dornyei, Zoltan. i Ushioda, Ema. 2011. Teaching and Researching Motivation (Second Edition). Harlow: Longman.

[10] Evaluacija eksperimentalnoga programa „Škola za život”. Preuzeto s: www.skolazazivot.hr (16. 8. 2019.)

[11] Gajić, Olivera. 2011. Interkulturalna dimenzija kurikuluma građanskog odgoja i demokratizacija obrazovanja. Pedagogijska istraživanja, 8 (1). 103-114. Retrived from: https://hrcak.srce.hr/118082 (25. 5. 2020.)

[12] Gortan-Carlin, Ivana Paula. i Močinić, Snježana. 2017. Iskustveno učenje i stjecanje glazbenih kompetencija učitelja razredne nastave. Školski vijesnik: časopis za pedagogijsku teoriju $i$ praksu 66 (4). 511-526. Retrived from: https://hrcak.srce.hr/index.php?show= clanak\&id_clanak_jezik=285671 (16. 4. 2020.)

[13] Grabovac, Mia i Slišković, Ana. 2015. Povezanosti obrazovnih očekivanja i ponašanja roditelja s različitim dimenzijama perfekcionizma njihove djece. Klinička psihlogija 8 (2). 111-124. Retrived from: https://hrcak.srce.hr/index.php?show $=$ clanak\&id_clanak jezik=250402 (12. 5. 2020.)

[14] Gutić, Dragutin i Rudelj, Siniša. 2012. Menadžment ljudskih resursa. Osijek: Grafika

[15] Hahl, Kaisa i Löfström, Erika. 2016. Conceptualizing interculturality in multicultural teacher education. Journal of Multicultural Discourses, 11 (3). 300-314. DOI: 10.1080/17447143.2015.1134544

[16] Haviland, William. 2004. Kulturna antropologija. Jastrebarsko: Naklada Slap.

[17] Hayes, Denis. 2009. Learning and Teaching in Primary Schools. Exeter: Learning Matters Ltd.

[18] Horga, Smiljka. 1993. Psihologija sporta. Zagreb: Fakultet za fizičku kulturu sveučilišta u Zagrebu.

[19] Jackson, Jane. 2014. Introducing language and intercultural communication. Oxon: Routledge.

[20] Jagić, Stjepan. 2006. Učenička putovanja u slobodnom vremenu. Odgojne znanosti, 8 (1(11)). 251-262. Retrived from: https://hrcak.srce.hr/26197 (2. 5. 2020.)

[21] Jogan Linić, Dajna. 2003. Motivacija u nastavi vjeronauka. Kateheza, 25 (1). 44-55. Retrived from: https://hrcak.srce.hr/113880 (8. 4. 2020.) 
[22] Juričić, Marko. 2006. Učenikovo opterećenje nastavom i razredno-nastavno ozračje. Odgojne znanosti, 8 (2). 330-332. Retrived from: https://hrcak.srce.hr/index.php? show=clanak\&id_clanak_jezik=33196 (12.4. 2020.)

[23] Kolak, Ante. 2015. Odgojni problemi u suvremenoj školi. Odgoj u školi, Ur. Opić, Siniša; Bilić, Vesna i Jurčić, Marko. 155-176. Zagreb: Učiteljski fakultet.

[24] Lafraya, Susana. 2011. Intercultural learning in non-formal education: theoretical frameworks and starting points. Paris: Council of Europe Retrived from: http://youthpartnership-eu.coe.int/youth-partnership/documents/Publications/Others 19501_Intercultural_learning_Lafraya_Final.pdf (25. 5. 2020.)

[25] Langlois, Judith H.; Kalakanis, Lisa; Rubenstein, Adam J.; Larson, Andrea; Hallam, Monica i Smoot, Monica. 2000. Maxims or myths of beauty? A meta-analytic and theoretical review. Psychological Bulletin, 126 (3). 390-423. DOI: 10.1037//00332909.126.3.390

[26] Lukaš, Mirko i Gazibara, Senka. 2010. Modaliteti suradničkih odnosa školskog pedagoga i roditelja. Život $i$ škola, 24. 210-215. Retrived from: https://hrcak.srce.hr/search/?show=results\&stype $=1 \& \mathrm{c} \% 5 \mathrm{~B} 0 \% 5 \mathrm{D}=\operatorname{article\_ search\& t} \% 5 \mathrm{~B}$ 0\%5D=modaliteti+suradni\%C4\%8Dkih+odnosa (15. 4. 2020.)

[27] Marzano, Robert; Pickering, Debra. J. i Polock, Jane. E. 2006. Nastavne strategije: kako primijeniti devet najuspješnijih nastavnih strategija. Zagreb: Educa.

[28] Mrkonjić, Anđelko i Vlahović, Jelena. 2008. Vrednovanje u školi. Zadar: Sveučilište u Zadru, odjel za pedagogiju.

[29] Ministarstvo znanosti, obrazovanja i sporta. 2006. Nastavni plan i program. Retrived from: https://www.azoo.hr/images/AZOO/Ravnatelji/RM/Nastavni_plan_i_program za_osnovnu_skolu_-_MZOS_2006_.pdf (13.5. 2020.)

[30] Ministarstvo znanosti, obrazovanja i sporta. 2010. Nacionalni okvirni kurikulum. Preuzeto s: http://mzos.hr/datoteke/Nacionalni_okvirni_kurikulum.pdf (13. 5. 2020.)

[31] Parsons, Talcott. 2007. American society: a theory of the societal community. Boulder: Paradigm Publication.

[32] Peko, Anđelka. 1999. Obrazovanje. Zagreb: Hrvatski pedagoško-književni zbor.

[33] Račić, Marta. 201). Modeli kompetencija za društvo znanja. Suvremene teme, 6 (1). 86-100. Preuzeto s: https://hrcak.srce.hr/112805 (20. 9. 2019.)

[34] Rogić, Ivan. 2003. Hrvatski nacionalni identitet i društvene elite. Hrvatski identitet u Europskoj uniji. Ur. Baloban, Stjepan. 13-51. Zagreb: Centar za promicanje socijalnog nauka Crkve, Glas Koncila.

[35] Rogulj, Nenad; Ujević, Kristina i Rogulj, Gordana. 2011. Prilog objektivnosti ocjene iz tjelesne i zdravstvene kulture u razrednoj nastavi. Život $i$ škola: časopis za teoriju $i$ praksu odgoja $i$ obrazovanja, 57 (26). 154-160. Retrived from: https://hrcak.srce.hr/index.php? show=clanak\&id_clanak_jezik=114768 (16. 5. 2020.)

[36] Sage, Nicole A. i Kindermann, Thomas. 1999. Peer networks, behavior contingencies and children's engagement in the classroom. Merrill-Palmer Quarterly, 454. 143-171. 
[37] Seifert, Kelvin i Sutton, Rosemary. 2009. Educational Psyhology, Second edition. Creative Commons Attribution 3.0 license.

[38] Official web site: „Škola za život“( $\underline{\text { www.skolazazivot.hr) }}$ (15. 4. 2020.)

[39] Tacol, Tonka. 2011. Ustvarjalno poučevanje in učenje pri pouku likovne vzgoje. Ljubljana: Univerza v Ljubljani, Pedagoška fakulteta.

[40] Taut, Sandy; Jiménez, Daniela; Puente-Duran, Sofia; Palacios, Diego; Inés Godoy, Maria i Manzi, Jorge. 2018. Evaluating thequality of teaching: can there be valid differentiation in the middle of the performance distribution?. School Effectiveness and School Improvement, 30 (3). 328-349 DOI: 10.1080/09243453.2018.1510842

[41] Vrcelj, Sofija. 2005. U potrazi za identitetom - iz perspektive komparativne pedagogije. Rijeka: Graftrade, Hrvatsko futurološko društvo.

[42] Vujčić, Vladimir. 2013. Opća pedagogija. Zagreb: HPKZ.

[43] Vukasović, Ante. 2001. Pedagogija (7. izdanje). Zagreb: Hrvatski katolički zbor Mi.

[44] Weinert, Franz. 1999. Definitions and Selection of Competencies. Concepts of Competence. Munich: Max Planc Institute.

[45] Weinert, Franz. 2001. Concept of competence: a conceptual clarification. Defining and selecting key competencies, 1. 45-66.

[46] Wigfield, Allan; Eccles, Jacquelynne. 2002. Development of Achivment Motivation. SAD: Academic Press

[47] Wigfield, Allan; Eccles, Jacquelynne; Roesser, Robert i Schiefele, Ulrich. 2008. Development of achievement motivation. Child and adolescent development. An advanced course. 406-434. New Jersey: John Wiley \& Sons.

[48] Wolters, Christopher. 2011. Regulation of motivation: Contextual and social aspects. Teachers College Record, 113 (2). 265-283.

[49] Zubić, Darija i Burušić, Josip. 2009. Fizička atraktivnost kao odrednica sociometrijskog statusa: moderirajući utjecaj samopoštovanja i socijalne anksioznosti. Suvremena psihologija, 12(1): 63-80. Retrived from: https://hrcak.srce.hr/82657 (28. 5. 2020.) 